
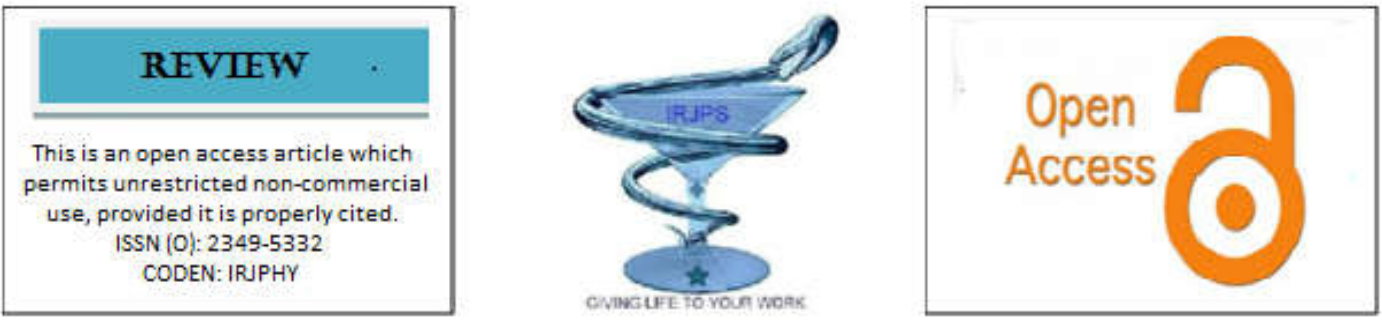

\title{
AWARENESS AND ATTITUDE TOWARDS COVID-19 IN HYDERABAD (INDIA) METROPOLITAN CITY - AN ONLINE SURVEY.
}

\author{
K. NAVYA SAI*, G. SNEHA VEENA, C. SUHAS REDDY.
}

Department of Pharmacy Practice, MLR Institute of Pharmacy, Hyderabad, Telangana, INDIA.

Submitted on: 20.12.2020; $\quad$ Revised on: 22.01.2021; $\quad$ Accepted on: 30.01 .2021

\begin{abstract}
:
Background: Corona virus disease 2019 (COVID-19) is a highly infectious disease. This virus was first identified in the month of December 2019 in Wuhan, China Hubei province. Since its first identification, it has spread globally. It was declared that COVID-19 is a public health emergency of international concern on January 30, 2020 by WHO. Despite all efforts the virus continues to spread and WHO declared it a pandemic on March 11, 2020.

Aims and Objectives: This study aims to assess the current level of knowledge towards COVID 19 among Hyderabad (India) residents and to analyze their attitudes and practices towards COVID 19 which is very important to break the cascade chain and to control this pandemic.

Material and Methods: This is a cross-sectional online study and a self-designed online questionnaire which was completed by the participants. There were a total of 34 questions among which 15 questions assessed knowledge, 9 questions assessed attitude and the remaining 10 questions assessed practice. The last section has a leaflet that consists of patient counselling points that describes the control and prevention of COVID-19. Results: A total of 200 people participated in the online survey out of which $99 \%$ people agree that hand washing is important to prevent the spread of disease. $95.5 \%$ believe that people who isolate themselves show that they have a responsibility in preventing the transmission of COVID-19. $99 \%$ have responded that staying at home when you are sick due to a common cold-like infection can reduce the spread of COVID-19.

Conclusion: The findings suggest that most of the people who participated in this study have a good level of knowledge on COVID-19 with a positive attitude and are practicing safety measures that are necessary for mitigating the spread of COVID-19. Efforts toward the knowledge regarding the use of antibiotics should be intensified by the government.
\end{abstract}

KEYWORDS: COVID-19, Knowledge, Attitude, Practice, Hyderabad.

Corresponding author: K. Navya Sai

Mob no: 8885150597

Email id: dr.navyakudapa@gmail.com
Indian Research Journal of Pharmacy and Science; 26(2020)2472-2482; Journal Home Page: https://www.irjps.in DOI: 10.21276/irjps.2020.7.4.9 


\section{INTRODUCTION:}

Coronavirus disease 2019 (COVID-19) is an illness caused by a novel coronavirus, now called Severe Acute Respiratory Syndrome Coronavirus 2 (SARS-CoV-2; formerly called 2019-nCoV). COVID-19 is an emerging respiratory infection that was first discovered in December 2019, in Wuhan city, Hubei Province, China ${ }^{1}$. The World Health Organization (WHO) declared coronavirus disease as a pandemic on March 11, 2020. In India, a confirmed case of COVID-19 was reported on 30th January 2020, who was a student travelled from Wuhan, China and has successfully recovered from the infection on 14th February 2020. Previously, the severe acute respiratory syndrome-coronavirus (SARS-CoV) and the Middle East respiratory syndrome-coronavirus (MERS-CoV) have been known to affect humans. MERS-CoV emerged in Saudi Arabia in 2012, The primary case was a Saudi national admitted in June 2012 with pneumonia and renal failure which resulted in a fatal outcome was found to be transmitted from Arabian camels to humans ${ }^{2}$, whereas SARS-CoV deadly clinical syndrome was brought to the attention of the WHO by Dr. Carlo Urbani and his colleagues in a Vietnamese hospital in February 2003was transmitted from civet cats to humans. SARS-CoV-2 seems to have originated from bats ${ }^{3}$.

Individuals with confirmed SARS-CoV-2 have clinical symptoms of fever, cough, and shortness of breath with an incubation period of 14 days following exposures to the virus. This virus spreads through respiratory droplets and by close contact from people to people. These respiratory droplets spread through breathing, touching the contaminated surfaces and then touching their face, nose, mouth and eyes. But the virus is not airborne. This virus can survive on surfaces for about 72 hours. From the time of exposure to onset, the symptoms show between 2-14 days, with an average of 5 days ${ }^{4}$. This COVID-19 causes morbidity in the range of mild respiratory illness to severe. Complications characterized by acute respiratory distress syndrome, septic shock, and other metabolic and haemostasis disorders and death. Most of the fatal cases and severe illnesses like acute respiratory distress syndrome (ARDS) occurred in older adults and folks who have underlying medical comorbidities like diabetes, cancer, hypertension, heart, lung, and kidney diseases. A scientific review on COVID-19 patients showed that individuals with hypertension, diabetes, cardiovascular and respiratory system diseases were the most vulnerable groups. Chronic obstructive pulmonary disease patients have a fivefold increased risk of severe COVID-19 infection. So far, no successful anti-viral treatment or vaccine has been reported. Therefore, applying the cautions to regulate COVID-19 infection is the utmost critical intervention. Accordingly, many countries across the world tried it by talking about different interventions including nationwide lockdown, varying levels of contact tracing and self-isolation or quarantine, and promotion of public health measures including handwashing, respiratory etiquette, and social distancing. However, the spread of COVD-19 continuously be alarmingly increasing from day to day and not controlled. Poor understanding of the disease among the community, especially the high-risk groups is implicated in this increase in the spread of the infection and death toll ${ }^{5}$.

People's observance of the prevention measures is important for controlling the spread of COVID-19, which is affected by their knowledge, attitudes, and practices (KAP) towards COVID-19. Therefore, we conducted a survey to investigate the KAP towards COVID-19 among the Hyderabad (India) residents during the period of the COVID-19 outbreak $^{6}$.

\section{MATERIALS AND METHODS:}

A cross-sectional survey was conducted from September $9^{\text {th }}, 2020$ to October $10^{\text {th }}, 2020$, a total of 200 people have responded to the KAP questions. Inclusion criteria contain all the individuals who are $\geq 18 y$ yrs of age, live in Hyderabad (India) metropolitan city. Exclusion criteria indicate people who do not have access to WhatsApp, Gmail and people who do not want to participate in the online survey.

\section{Questionnaire and data collection}

A self-designed online questionnaire was prepared using google forms and was send to potential responders who are residing in Hyderabad. The questionnaire consists of five sections in which the first section contains the consent form along with the demographic details, the second section has 15 questions relating to knowledge towards COVID19 , the third section has 9 questions relating to attitude and similarly, the fourth section has 10 practice questions. The last section has a leaflet that 
consists of patient counselling points that describes the control and prevention of COVID-19. A google form link was sent to people through what's app and Gmail. A convenient sampling method was used to collect the data which was further divided into five variables like, gender (male, female),
Marital status (single, married), Age was divided into four categories (18-21years, 22-25years, 2629years, >30years), Education (below education, pursuing education, graduate, post-graduate) and Profession (unemployed, employed, healthcare, IT).

Table 1: Demographic details of population.

\begin{tabular}{|c|c|c|c|}
\hline Variable & Categories & N & Percentage \\
\hline Gender & Male & 86 & 43 \\
\hline & Female & 114 & 57 \\
\hline Age & $18-21$ years & 20 & 10 \\
\hline & $22-25$ years & 90 & 45 \\
\hline & $26-29$ years & 34 & 17 \\
\hline $\begin{array}{c}\text { Marital } \\
\text { Status }\end{array}$ & $>30$ years & 56 & 28 \\
\hline & Single & 126 & 63 \\
\hline Education & Married & 74 & 37 \\
& Below & 03 & 1.5 \\
\hline & Praduation & & 11.5 \\
& Graduation & 23 & 47 \\
\hline & Graduation & 94 & 40 \\
\hline & Post-Graduation & 80 & 23 \\
\hline Profession & Unemployed & 46 & 41.5 \\
\hline & Employed & 83 & 12.5 \\
\hline & Healthcare & 25 & 23 \\
\hline & IT & 46 & \\
\hline
\end{tabular}

\section{Statistical analysis}

Statistical analysis was performed for knowledge, attitude, and practice questions, a T-value was determined using the mean and standard deviation. Each variable is divided into sub-categories and a comparison was obtained. For example, male and female sub-categories were compared to know which group of people have more knowledge, attitude, and practice towards COVID-19.

\section{RESULTS:}

A total of 200 people participated in our online survey. Frequency and percentages of demographic characteristics like age, gender and marital status of participants were collected. Among them 86(43\%) are male and $114(57 \%)$ are female. The age of the participants ranges from 18 yrs and above, the majority of the responders are of the age group 2225 years are $90(45 \%)$ followed by $56(28 \%)$ are above 30 years old, 20(10\%) are of 18-21 years old and $34(17 \%)$ are $26-29$ years. $126(63 \%)$ are single and the remaining $74(37 \%)$ are married.The responder's background details were also collected which includes their level of education and profession. Among 200 participants, the majority of them were graduated $94(47 \%)$ followed by postgraduation $80(40 \%), 23(11.5 \%)$ are pursuing their graduation and only $3(1.5 \%)$ are of below graduation. The profession includes categories of Unemployed, employed, health care and IT. Of which the $83(41.5 \%)$ are employed, followed by $46(23 \%)$ are unemployed and IT, while the remaining $25(12.5 \%)$ belong to health care completed the survey. 


\section{DEMOGRAPHIC DETAILS:}

\section{KNOWLEDGE $\left(n_{1}\right)$ :}

The knowledge was assessed based on the demographic characteristics by comparing their means and standard deviations. The mean knowledge score of gender includes 2.66 of male with standard deviation 0.65 whereas, the mean value of female is 2.68 with S.D 0.59 and the $t$ value found was found to be 0.227 .

There are different age groups having knowledge on COVID-19 in the age group of 18-21years with mean of 2.71 and S.D of 0.61 , followed by mean values of 2.67, 2.66, 2.67 and standard deviation of $0.61,0.64$, and 0.605 respectively with the age groups of 22-25 years, 26-29 years and above 30 years respectively. $\mathrm{T}$ value for this age group is 0.265 .

The means and standard deviation was assessed with marital status, found that single have mean of 2.68 and S.D of 0.61 , whereas 2.67 mean and S.D 0.62 with married people and the knowledge was assessed by comparing the means and standard deviation with the level of education which includes below graduation and people pursuing graduation having the means of 2.71 and 2.66 with S.D of $0.19,0.25$ respectively. T value was found to be 0.23 . Whereas2.68 Mean and S.D of 0.21 in graduates and post-graduated people attained a mean of 2.68 with standard deviation 0.22 and $T$ value was 0.556

The means and standard deviation were compared among unemployed and employed, health care and IT. The mean value of unemployed and employed is $2.65,2.68$ and S.D of $0.64,0.59$ respectively with $\mathrm{T}$ value 0.268 , whereas in the health care mean was 2.69 with S.D 0.65 and in IT people the mean value was found to be 2.67 with S.D 0.62.T value was found 0.191 .

\section{KNOWLEDGE WISE DISTRIBUTION OF POPULATION:}

The majority of the responses are correct under the knowledge section except for one question which relates to antibiotic use in the treatment for COVID-19. 93 (46.5) people responded true and 58 (29) people responded false and 49 (24.5) people do not know the answer. The remaining answer rates were given in the below table.

Table 2: Knowledge based distribution of population.

\begin{tabular}{|c|c|c|c|c|c|}
\hline Variable & Knowledge $\left(\mathbf{n}_{\mathbf{1}}\right)$ & Mean & SD & T-value & P-value \\
\hline Gender & Male & 2.661 & 0.650 & & \\
\hline & Female & 2.689 & 0.596 & 0.227 & 0.8205 \\
\hline Age & $18-21$ & 2.712 & 0.614 & & \\
\hline & $22-25$ & 2.672 & 0.611 & 0.265 & 0.7913 \\
\hline & $26-29$ & 2.667 & 0.642 & & \\
\hline & $>30$ & 2.679 & 0.605 & 0.075 & 0.9406 \\
\hline Marital & Single & 2.680 & 0.616 & & \\
\hline status & Married & 2.672 & 0.626 & 0.111 & 0.9115 \\
\hline & Below Graduation & 2.717 & 0.199 & & \\
\hline & Pursuing Graduation & 2.666 & 0.252 & 0.23 & 0.81 \\
\hline & Graduation & 2.685 & 0.215 & & \\
\hline & Post-graduation & 2.685 & 0.224 & 0.556 & 0.57 \\
\hline Profession & Unemployed & 2.657 & 0.640 & & \\
\hline & Employed & 2.689 & 0.595 & 0.268 & 0.78 \\
\hline & Healthcare & 2.695 & 0.656 & & \\
\hline & IT & 2.673 & 0.625 & 0.191 & 0.848 \\
\hline
\end{tabular}




\section{QUESTIONNAIRE OF KNOWLEDGE TOWARDS COVID-19:}

Table 3: Responses to questionnaire regarding COVID-19.

\begin{tabular}{|c|c|c|c|c|}
\hline S.NO & QUESTIONS & $\begin{array}{l}\text { TRUE } \\
{[n(\%)]}\end{array}$ & $\begin{array}{l}\text { FALSE } \\
{[\text { [ (\%)] }}\end{array}$ & $\begin{array}{c}\text { I DON'T KNOW [n } \\
(\%)]\end{array}$ \\
\hline 1. & $\begin{array}{l}\text { Fever, cough, breathlessness, sore throat are the } \\
\text { common symptoms of COVID-19? }\end{array}$ & $\begin{array}{c}193 \\
(96.5) \\
\end{array}$ & $2(1)$ & $5(2.5)$ \\
\hline 2. & $\begin{array}{l}\text { Does eating or contacting wild animal's results in } \\
\text { COVID-19 infection? }\end{array}$ & $39(19.5)$ & $132(66)$ & $29(14.5)$ \\
\hline 3. & $\begin{array}{l}\text { Is it possible for a COVID-19 positive person to } \\
\text { show NO symptoms? }\end{array}$ & $\begin{array}{c}171 \\
(85.5)\end{array}$ & $19(9.5)$ & $10(5)$ \\
\hline 4. & Is hand-wash important? & $198(99)$ & $1(0.5)$ & $1(0.5)$ \\
\hline 5. & $\begin{array}{l}\text { Antibiotics are an effective treatment for COVID- } \\
19\end{array}$ & $93(46.5)$ & $58(29)$ & $49(24.5)$ \\
\hline 6. & $\begin{array}{l}\text { Currently, there is no effective cure for COVID-19, } \\
\text { but early symptomatic and supportive treatment can } \\
\text { help most patients recover from the diseases. }\end{array}$ & $188(94)$ & $2(1)$ & $10(5)$ \\
\hline 7. & $\begin{array}{l}\text { Older adults and those with serious chronic } \\
\text { illnesses, such as heart or lung disease and diabetes, } \\
\text { are at increased risk of developing more serious } \\
\text { complications from COVID-19? }\end{array}$ & $\begin{array}{c}189 \\
(94.5)\end{array}$ & $3(1.5)$ & $8(4)$ \\
\hline 8. & $\begin{array}{l}\text { Pregnant women are more susceptible to infections } \\
\text { than non-pregnant women? }\end{array}$ & $118(59)$ & $34(17)$ & $48(24)$ \\
\hline 9. & $\begin{array}{l}\text { Healthy food and drinking water increase the } \\
\text { body's immunity and resistance to COVID-19 }\end{array}$ & 188 (94) & 6(3) & $6(3)$ \\
\hline 10. & $\begin{array}{c}\text { People in contact with someone infected with } \\
\text { SARS-CoV-2 should be immediately quarantined, } \\
\text { in an appropriate location, for a general observation } \\
\text { period of } 14 \text { days? }\end{array}$ & $182(91)$ & $4(2)$ & $14(7)$ \\
\hline 11. & $\begin{array}{l}\text { To prevent transmission of SARS-CoV-2, people } \\
\text { must avoid going to crowded places and avoid } \\
\text { taking public transport? }\end{array}$ & $188(94)$ & $5(2.5)$ & $7(3.5)$ \\
\hline
\end{tabular}

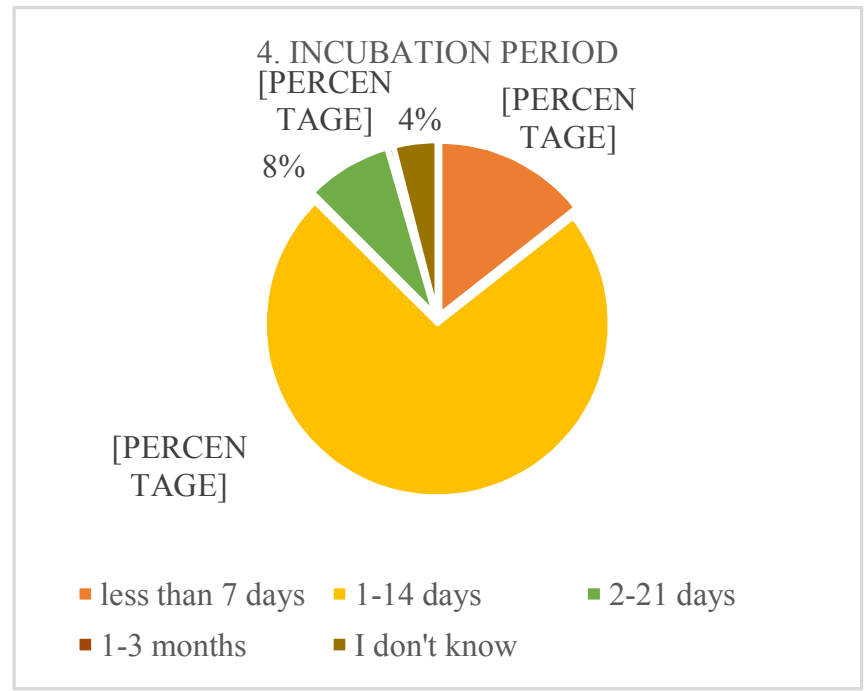

Graph 1: Percentage of knowledge on incubation period

Most of the respondents $(73 \%)$ say that the incubation period is 1-14 days and $14.4 \%$ responded that it will take less than 7 days to show the symptoms. $8 \%$ have chosen $2-21$ days whereas $4 \%$ do not know the answer and only $1 \%$ have responded as 1-3months. 


\section{WHO CAN GET INFECTED WITH COVID-19}

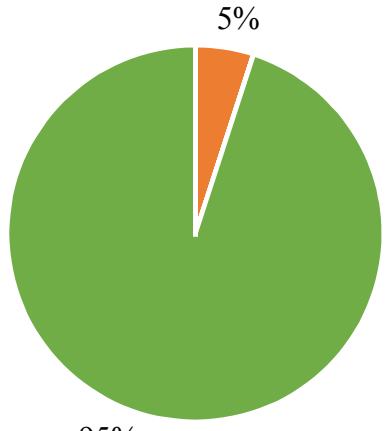

$95 \%$

- old people only $\quad$ young adults only

- anyone can be affected - teenagers and children only

Graph 2: Percentage of people'sknowledge on getting COVID-19 based on their age groups.

A vast majority of them $(95 \%)$ responded as that only old people are infected with the virus. anyone can be infected by COVID-19 and 5\% say

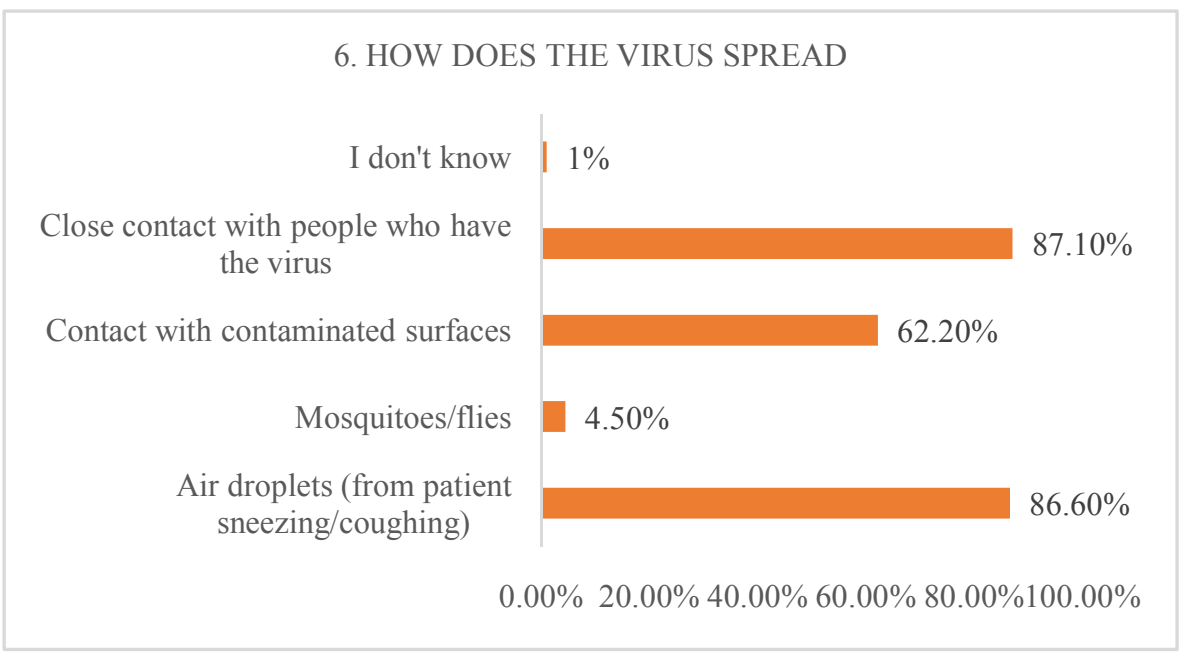

Graph 3: Percentage of knowledge on mode of transmission of virus.

We got different responses towards the transmission of the virus, $174(86.6 \%)$ say that virus is transmitted through air droplets, 9 (4.5\%) people say that mosquitoes/flies can spread the disease. $125(62.2 \%)$ also responded that it might be transmitted through contact with contaminated surfaces $175(87.1 \%)$ states that close contact with the infected person and two people do not know the route of transmission. 


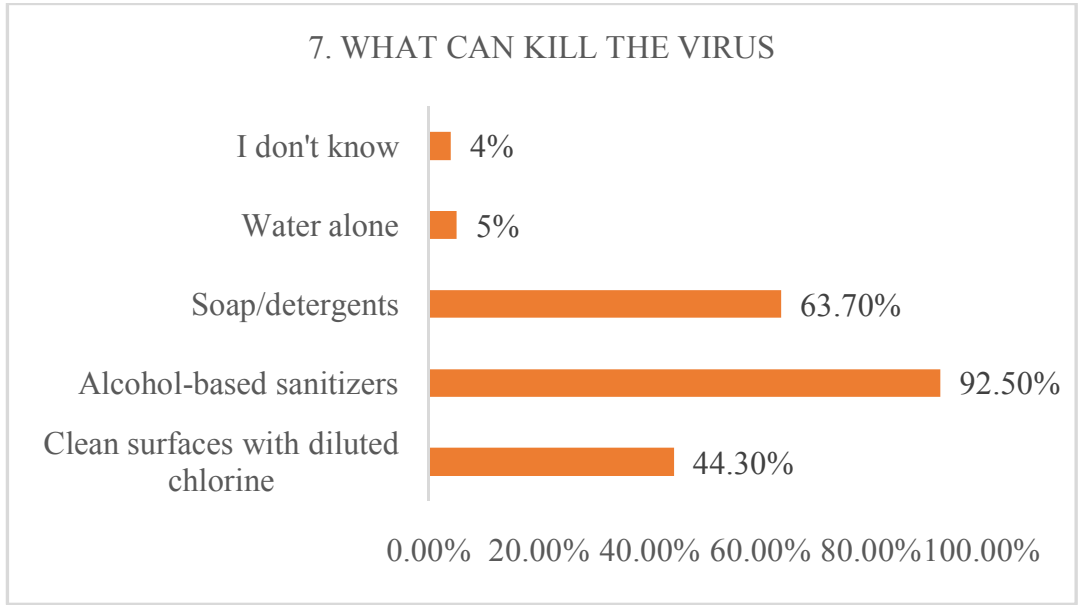

Graph 4: Percentage of knowledge on termination of virus

The majority of the people say that using alcoholbased sanitizers and soap/detergents can kill the virus but $89(44.3 \%)$ responded that clean surfaces with chlorine and $10(5 \%)$ responded that water alone can kill the virus. $8(4 \%)$ do not know the answer.

\section{ATTITUDE ( $\left.\mathbf{n}_{2}\right)$ :}

The below table describes the attitude of mean and standard deviation of different variables along with their t-value and p-value.

\section{ATTITUDE WISE DISTRIBUTION OF POPULATION:}

Table 4: Attitude based distribution of population.

\begin{tabular}{|l|l|l|l|l|l|}
\hline Variable & Attitude $\left.\mathbf{( n}_{\mathbf{2}}\right)$ & Mean & SD & T-value & P-value \\
\hline Gender & Male & 2.697 & 0.445 & & \\
\hline Age & Female & 2.706 & 0.418 & 0.165 & 0.8687 \\
\hline & $18-21$ years & 2.669 & 0.504 & & \\
\hline & $22-25$ years & 2.765 & 0.381 & 1.002 & 0.3186 \\
\hline & $26-29$ years & 2.663 & 0.470 & & \\
\hline Marital status & $>30$ years & 2.657 & 0.476 & 0.098 & 0.9223 \\
\hline & Single & 2.680 & 0.616 & & \\
\hline Education & Married & 2.672 & 0.626 & 0.111 & 0.9121 \\
\hline & $\begin{array}{l}\text { Below } \\
\text { Graduation }\end{array}$ & 2.809 & 0.235 & & \\
\hline & $\begin{array}{l}\text { Pursuing } \\
\text { graduation }\end{array}$ & 2.648 & 0.357 & 0.33 & 0.74 \\
\hline & Graduation & 2.726 & 0.408 & & \\
\hline Profession & Post-graduation & 2.755 & 0.280 & 2.26 & 0.24 \\
\hline & Unemployed & 2.714 & 0.431 & & \\
\hline & Employed & 2.690 & 0.454 & 0.246 & 0.806 \\
\hline & Healthcare & 2.788 & 0.359 & & \\
\hline & IT & 2.675 & 0.449 & 1.15 & 0.25 \\
\hline
\end{tabular}

$98(49 \%)$ people believed in preventing the global pandemic in the future, whereas 88 (44\%) people have no idea about it and the remaining 14 (7\%) have no belief in preventing the global pandemic. $168(84 \%)$ people are willing to read and share the right information regarding covid-19, while others $9(4.5 \%)$ are not willing and $23(11.5 \%)$ may show interest to share the information. 101(50.5\%) people believed in successful control of covid-19 while $23(11.5 \%)$ people has no belief in controlling the pandemic and $76(38 \%)$ people are thinking that covid-19 might be controlled. Most of them say that drinking alcohol will not cure COVID-19 and $180(90 \%)$ responded that everyone will not die 
with COVID-19. A vast majority of them (91.5\%) said that a negative stigma should not be given to the infected patients and 191 (95.5\%) people who isolate themselves show social responsibility in preventing the transmission of COVID-19.

\section{QUESTIONNAIRE OF ATTITUDE TOWARDS COVID-19:}

Table 5: Responses to questionnaires on attitude towards COVID-19.

\begin{tabular}{|c|l|l|l|l|}
\hline S.NO & QUESTIONS & YES & NO & MAYBE \\
\hline $\mathbf{1 .}$ & $\begin{array}{l}\text { Do you think we can prevent such a global } \\
\text { pandemic in the future? }\end{array}$ & $98(49)$ & $14(7)$ & $88(44)$ \\
\hline $\mathbf{2 .}$ & $\begin{array}{l}\text { Are you willing to read and share with others the } \\
\text { right information about COVID-19? }\end{array}$ & $168(84)$ & $9(4.5)$ & $23(11.5)$ \\
\hline $\mathbf{3 .}$ & COVID-19 can finally be successfully controlled? & $101(50.5)$ & $23(11.5)$ & $76(38)$ \\
\hline $\mathbf{4 .}$ & Drinking alcohol will not cure COVID-19 & $155(77.5)$ & $32(16)$ & $13(6.5)$ \\
\hline $\mathbf{5 .}$ & Not everyone with COVID-19 will die & $180(90)$ & $11(5.5)$ & $9(4.5)$ \\
\hline $\mathbf{6 .}$ & $\begin{array}{l}\text { People with COVID-19 should not be given a } \\
\text { negative stigma in society }\end{array}$ & $183(91.5)$ & $4(2)$ & $13(6.5)$ \\
\hline $\mathbf{7 .}$ & $\begin{array}{l}\text { People with COVID-19 who isolate themselves } \\
\text { show that they have a responsibility in preventing } \\
\text { the transmission of COVID-19 }\end{array}$ & $191(95.5)$ & $1(0.5)$ & $8(4)$ \\
\hline
\end{tabular}

$24.4 \%$ of people are satisfied and felt updated regarding the information provided by the social media about the covid19 pandemic, whereas $22.4 \%$ found that there are more lies, $18.9 \%$ felt very stressed about the information, $16.9 \%$ opted that there was no complete information provided, $10.4 \%$ did not comment on the social media coverage remaining $7 \%$ people do not follow any social mediate updates.

\section{HOW SATISFIED ARE YOU WITH MEIDA/SOCIAL MEDIA COVERAGE}

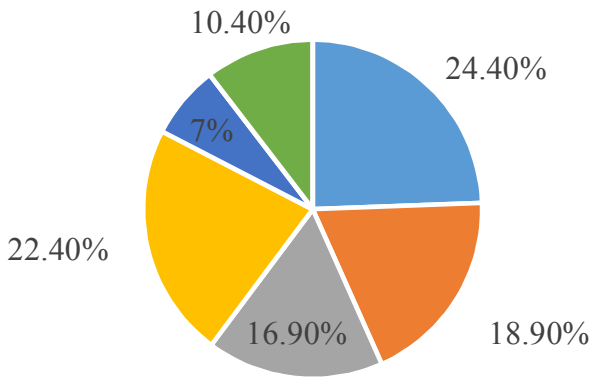

- Very satisfied/keeps me updated - Makes me worry more/stressful

- Not enough information $\quad$ - There are more lies than truth

- I don't follow any media update - No comment

Graph 5: Attitude towards social media coverage 


\section{WHAT DO YOU THINK WE CAN DO AS A COMMUNITY} TO REDUCE THE SPREAD

\section{I don't know I $1.50 \%$}

Avoid handshakes and face kissing

Volunteer to support whenever.

Social distancing/avoid crowd

Attending religious gatherings

Eat healthy/practice sports

Follow/respect the health.

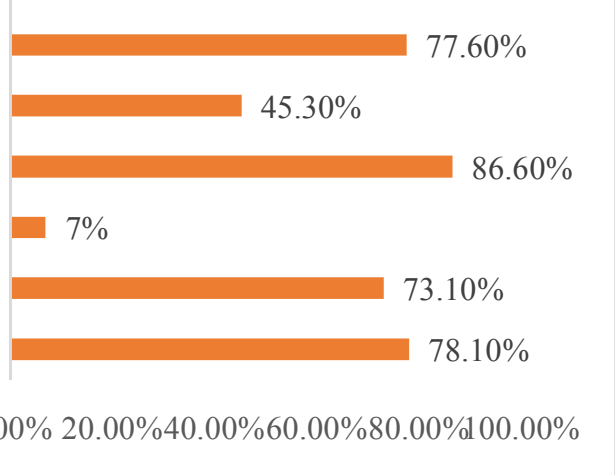

Graph 6: Attitude of the participants on reducing the spread of COVID-19

The majority of people are trying to reduce the spread of this COVID-19 pandemic. Among them $174(86.6 \%)$ believed in social distancing/avoid crowding, $157(78.1 \%)$ have chosen to follow the health recommendations, $156 \quad(77.6 \%)$ avoid handshakes/face kissing, 147 (73.1\%) eat healthy foods/practice sports, $91(45.3 \%)$ will volunteer to support whenever possible and surprisingly 14
(7\%) have respondent that attending religious gathering can reduce the spread of COVID-19. Only $3(1.5 \%)$ do not know the answer.

\section{PRACTICE $\left(\mathbf{n}_{3}\right)$ :}

The below table describes the practice of mean and standard deviation of different variables along with their t-value and p-value.

\section{PRACTICE WISE DISTRIBUTION OF POPULATION:}

Table 6: Practice based distribution of population.

\begin{tabular}{|l|l|l|l|l|l|}
\hline Variable & Practice $\left(\mathbf{n}_{\mathbf{3}}\right)$ & Mean & SD & T-value & P-value \\
\hline Gender & Male & 2.481 & 0.828 & & \\
\hline Age & Female & 2.515 & 0.832 & 0.254 & 0.7995 \\
\hline & $18-21$ years & 2.368 & 0.886 & & \\
\hline & $22-25$ years & 2.531 & 0.813 & 0.836 & 0.4051 \\
\hline & $26-29$ years & 2.482 & 0.845 & & \\
\hline Marital status & $>30$ years & 2.503 & 0.841 & 0.110 & 0.9130 \\
\hline & Single & 2.504 & 0.824 & & \\
\hline Education & Married & 2.483 & 0.856 & 0.164 & 0.8697 \\
\hline & $\begin{array}{l}\text { Below } \\
\text { graduation }\end{array}$ & 2.8 & 1.319 & & \\
\hline & $\begin{array}{l}\text { Pursuing } \\
\text { graduation }\end{array}$ & 2.498 & 0.953 & 0.606 & 0.55 \\
\hline & Graduation & 2.434 & 0.965 & & \\
\hline & Post-graduation & 2.515 & 0.940 & 0.139 & 0.88 \\
\hline Profession & Unemployed & 2.504 & 0.846 & & \\
\hline & Employed & 2.477 & 0.838 & 0.196 & 0.845 \\
\hline & Healthcare & 2.52 & 0.815 & & \\
\hline & IT & 2.516 & 0.786 & 0.05 & 0.95 \\
\hline
\end{tabular}

Most of the respondents have good practice

towards COVID-19 which were listed in the below table. 


\section{QUESTIONNAIRE OF PRACTICE TOWARDS COVID-19:}

Table 7: Responses to questionnaire of practice towards COVID-19.

\begin{tabular}{|c|c|c|c|}
\hline S.NO & QUESTIONS & YES & NO \\
\hline 1. & $\begin{array}{l}\text { Do you participate in meetings, religious activities, events, and other social } \\
\text { gatherings or any crowded place in areas with ongoing community } \\
\text { transmission? }\end{array}$ & $22(11)$ & $178(89)$ \\
\hline 2. & $\begin{array}{l}\text { Do you practice "physical distancing" by remaining } 6 \text { feet } / 2 \text { meters away from } \\
\text { others at all times? }\end{array}$ & $186(93)$ & $14(97)$ \\
\hline 3. & Do you limit contact (such as handshakes) & $196(98)$ & $4(2)$ \\
\hline 4. & Do you eat or drink in bars and restaurants? & $14(7)$ & $186(93)$ \\
\hline 5. & $\begin{array}{l}\text { Do you cover your nose and mouth during coughing or sneezing with the } \\
\text { elbow or a tissue, then throw the tissue in the trash }\end{array}$ & $194(97)$ & $6(3)$ \\
\hline 6. & $\begin{array}{l}\text { Do you stay home when you were sick due to common cold-like infection } \\
\text { during the transmission period }\end{array}$ & $198(99)$ & $2(1)$ \\
\hline 7. & Do you listen and follow the direction of your state and local authorities? & $196(98)$ & $4(2)$ \\
\hline 8. & Do you Follow WHO hand-washing technique & $170(85)$ & $30(14)$ \\
\hline 9. & $\begin{array}{l}\text { In the last few days, I have taken vitamins or supplements to increase my } \\
\text { immune system }\end{array}$ & $141(70)$ & $59(29)$ \\
\hline 10. & In the last few days, I have been washing my hand with soap more frequently & $182(91)$ & $18(9)$ \\
\hline
\end{tabular}

\section{DISCUSSION:}

Currently, the alarmingly spread of COVID-19 is a major public issue in the world. Till now no treatment or vaccine is discovered. Therefore, prevention is the best solution.In the present study, the knowledge, attitude, and practice towards COVID-19 were assessed in the people living in Hyderabad. The study was dominated by females $(57 \%)$ and $45 \%$ of people come under the $22-25$ years age group and more than half of them are single $(63 \%)$. Results indicate that nearly half of the population have completed graduation $(47 \%)$ and are employed (41.5\%).

Knowledge score indicates that females have more knowledge than males which is in accordance with Muhammad Saefet.al.,a study conducted among Indonesian undergraduate students ${ }^{7}$.Age category which is between 18-21 has greater knowledge and Singles have slightly more knowledge than the married group of people.Surprisingly, below education group have more knowledge than other group of people. The range of correct answers to Knowledge questions among participants in our study was better than those of other groups of population. This is probably due to better medical knowledge among participants in the healthcare sector. This is in agreement with the study conducted by Hussain Asrafet.al.,among Nepalese residents ${ }^{8}$.

The majority of respondents have a positive attitude towards COVID-19 which is in accordance with the study conducted by Bao-Liang Zhonget.al.,among Chinese residents ${ }^{9}$.The optimistic attitude of the Hyderabad people could be related to the unprecedented COVID-19 control measures such as traffic limits all throughout India and the shutdown of the complete Telangana state which enhance people's confidence in winning the battle against the virus. Second, the concerted efforts from across the country also increase the Hyderabad people's confidence to overcome the pandemic.

Participants of our study had optimistic attitudes towards COVID-19. Most of them took precautions to prevent infection by COVID-19, not going to crowded places and wearing masks when leaving home. These preventive practices could be primarily attributed to the very strict prevention and control measures implemented by the government such as banning public gatherings. Secondly, they also could be the result of strict lockdown. Third, they also could be the result of the residents' good knowledge regarding the high infectivity of the COVID-19 virus, which can be easily transmitted between people via invisible respiratory droplets. Our study is in accordance with Carlos Miguel Rios-Gonzálezet.al., who has conducted a study in Paraguayans ${ }^{10}$.

\section{CONCLUSION:}

The findings suggest that most of the people who participated in this study have a good level of knowledge on COVID-19 with a positive attitude and are practicing safety measures that are necessary for mitigating the spread of COVID- 19 . Efforts toward the knowledge regarding the use of antibiotics should be intensified. 


\section{AKNOWLEDGEMENT:}

We warmly thank all the study participants for their voluntary participation and for providing essential information.

\section{REFERENCES:}

1. Mohammed K. Al-Hanawi $1 * \dagger$, Khadijah Angawi 1, Noor Alshareef 1 , Ameerah M. N. Qattan1, Hoda Z. Helmy 1, Yasmin Abudawood1, Mohammed Alqurashi 1, Waleed M. Kattan1, Nasser Akeil Kadasah2 , GowokaniChijere Chirwa3,4† and Omar Alsharqi 1. Knowledge, Attitude and Practice Toward COVID-19 Among the Public in the Kingdom of Saudi Arabia: A CrossSectional Study. Frontiers in public health. 2020;8:217

2. Hamzah Z. Farooqa,b,c, *, Emma Daviesa,c , ShazaadAhmada,b,c , Nicholas Machina,c,d , Louise Hesketha,c,d , Malcolm Guiver. Middle East respiratory syndrome coronavirus (MERS-CoV) Surveillance and testing in North England from 2012 to 2019. International journal of infectious disease. 2020;93:237-44.

3. Kathryn V. Holmes. SARS coronavirus: a new challenge for prevention and therapy. J Clin Invest. 2003;111(11):1605-9.

4. Pandey S, GuptaA.Bhansali R, BalharaS, KatiraP and Fernandes G. Corona Virus (COVID-19) Awareness Assessment - A Survey Study Amongst the Indian Population. J Clin Med Res. 2020;2(4):111.

5. YonasAkalu 1 BirhanuAyelign 2 MeseretDerbewMolla. Knowledge, Attitude and Practice Towards COVID-19
Among Chronic Disease Patients at Addis

Zemen Hospital, Northwest Ethiopia. Infection and Drug Resistance 2020;13: 1949-60.

6. SonamMaheshwari1, Puneet Kumar Gupta2*, Richa Sinha1, PraveshRawat. Knowledge, attitude, and practice towards coronavirus disease 2019 (COVID-19) among medical students: A cross-sectional study. J Acute Dis 2020; 9(3): 100-4.

7. Muhammad Saefia , Ahmad Fauzi b,* , EviKristianac , WidiCahyaAdi d, M. Muchsona , M. EvalSetiawane , Novita NurulIslamif , Dian Eka Aprilia FitriaNingrumg , M. AlifudinIkhsanh, MavindraRamadhani. Survey data of COVID-19-related knowledge, attitude, and practices among indonesian undergraduate students. Data in brief 2020;31: 105855.

8. Hussain Asraf1 ,Tripathi Garima2, Bishnu Mohan Singh3, Ramji Ram4, Raman Pal Tript. Knowledge, attitudes, and practices towards COVID-19 among Nepalese Residents: A quick online crosssectional survey. Asian Journal of Medical Sciences 2020:11(3).

9. Zhong BL, Luo W, Li HM, Zhang QQ, Liu XG, Li WT, Li Y. Knowledge, attitudes, and practices towards COVID19 among Chinese residents during the rapid rise period of the COVID-19 outbreak: a quick online cross-sectional survey. Int J BiolSci 2020;16(10):1745-52.

10. Carlos Miguel, Rios González. Knowledge, attitudes and practices towards COVID-19 in Paraguayans during outbreaks: a quick online survey. 2020; https://doi.org/10.1590/SciELOPreprints.1 4 